\title{
Innoversity in knowledge-for-action
} and adaptation to climate change: the first steps of an 'evidence-based climatic health' transfrontier training program

\author{
This article was published in the following Dove Press journal: \\ Advances in Medical Education and Practice \\ 21 December 2010 \\ Number of times this article has been viewed
}

\author{
Véronique Lapaige ${ }^{1-3}$ \\ Hélène Essiembre ${ }^{4}$ \\ 'Department of Psychiatry, University \\ of Montreal, Montreal, QC, Canada; \\ ${ }^{2}$ Fernand-Seguin Research Centre, \\ Montreal, QC, Canada; ${ }^{3}$ Quebec \\ National Public Health Institute, \\ ${ }^{4}$ Industrial and Organizational \\ Program, Department of Psychology, \\ University of Montreal, Montreal, QC, \\ Canada
}

Abstract: It has become increasingly clear to the international scientific community that climate change is real and has important consequences for human health. To meet these new challenges, the World Health Organization recommends reinforcing the adaptive capacity of health systems. One of the possible avenues in this respect is to promote awareness and knowledge translation in climatic health, at both the local and global scales. Within such perspective, two major themes have emerged in the field of public health research: 1) the development of advanced training adapted to 'global environment' change and to the specific needs of various groups of actors (doctors, nurses, public health practitioners, health care managers, public service managers, local communities, etc) and 2) the development of strategies for implementing research results and applying various types of evidence to the management of public health issues affected by climate change. Progress on these two fronts will depend on maximum innovation in transdisciplinary and transsectoral collaborations. The general purpose of this article is to present the program of a new research and learning chair designed for this double set of developmental objectives - a chair that emphasizes 'innoversity' (the dynamic relationship between innovation and diversity) and 'transfrontier ecolearning for adaptive actions'. The Écoapprentissages, santé mentale et climat collaborative research chair (University of Montreal and Quebec National Public Health Institute) based in Montreal is a center for 'transdisciplinary research' on the transfrontier knowledge-for-action that can aid adaptation of the public health sector, the public mental health sector, and the public service sector to climate change, as well as a center for complex collaborations on evidence-based climatic health 'training'. This program-focused article comprises two main sections. The first section presents the 'general' and 'specific contexts' in which the chair emerged. The 'general context' pertains to the health-related challenge of finding ways to integrate, transfer, and implement knowledge, a particularly pointed challenge in Canada. The 'specific context' refers to the emerging research field of adaptation of public health to climate change. In the second section, the characteristics of the research chair are more extensively detailed (the vision of 'innoversity' and 'transfrontier knowledge-for-action,' the approach of shared responsibility and complex collaboration, objectives, and major axes of research). We conclude with a call for complex collaboration toward knowledge-for-action in public health services/mental health services/public services' adaptation to climate change: this call is aimed at individual and institutional actors in the North and South/West and East concerned by these issues.

Keywords: global changing environment, climatic health, adaptation to climate change, adaptive capacity, innoversity, diversity, complex collaboration, transdisciplinary knowledge-for-action, transfrontier training, andragogy, continuing education, ecocompetency, public health, mental 
health, health professional, public service manager, knowledge translation, implementation science, ecolearning, ecomanagement, ecodecision-making

\section{Introduction}

Globalization today constitutes a major challenge $\mathrm{e}^{1-4}$ for the public health sector and its involved professionals (Ciliska ${ }^{5}$ defines 'public health professionals' as 'first-line' clinicians and workers, researchers, managers, and decision makers in public health). These professionals are collectively concerned with achieving an eco-socio-efficient public health as well as the steady growth of an equitable public health system. ${ }^{1-3,6-10}$ The globalization challenge parcels out into several 'inherently global health issues, ${ }^{8}$ such as the struggle against climate change and drought, the establishment of international rules for migrant labor, the fight against poverty and for health equity, the management of fallout from natural catastrophes, and the fight against infectious disease (Figure 1). In the context of global social and environmental change, these globalization-related issues are all actively present and constitute meaningful targets for the efforts of professionals of the new 'globalized public health'. ${ }^{4}$

At another level, we find a second major challenge for globalized public health: knowledge-for-action or knowledge translation (KT). ${ }^{11-13}$ This is a transversal challenge because it cuts across the issues raised by globalization mentioned previously (Figure 1), ${ }^{4,14}$ In an era of hyperconnectivity and the global economy of knowledge, ${ }^{15-17}$ this transversal challenge is inherent in the valorization of knowledge as well as the updating and transfer of knowledge for each contemporary public health issue. ${ }^{14,18}$ This challenge is often referred to in public health circles as that of the 'integration' ${ }^{13,18-29}$ of multilevel knowledge, of the 'transfer' of knowledge toward decision makers or again, of the knowledge-for-action (KT), ie, the 'practical implementations' or 'exemplary behaviors'. ${ }^{11,12,30-35}$

The 'big issue,' in the Quebec/Canadian context, is climate change (ie, local Agenda 21). ${ }^{36,37}$ At a larger scale, as reported by the UCL-Lancet Commission, 'climate change is the biggest global health threat of the $21 \mathrm{st}$ century'. ${ }^{38}$ Several considerations motivate this priority:

- Unequivocal recognition of the importance of this phenomenon by the international scientific community ${ }^{39}$

- Universal recognition of the unprecedented priority of this phenomenon by local, ${ }^{40-48}$ regional, and worldwide ${ }^{49-53}$ governmental and scientific bodies, given the intensive (rapid and severe) and extensive (present and projected) nature of the inherent risks

- Major health risks resulting from local, ${ }^{37,54-58}$ regional, and worldwide ${ }^{59-66}$ climate change, particularly with respect to certain vulnerable populations and regions
- Repeated calls at various levels ${ }^{7,41,49,55,56,66-78}$ for reinforcement of the 'adaptive capacity' of the health systems that are faced with the challenges of climate change

- The necessity for collaborative and integrated intersectoral action that will reinforce transfer of knowledge toward health professionals and increase awareness in the general population of current challenges arising from climate change: these collaborative actions should aim at 'adaptive,' evidence-based, and effective risk management. ${ }^{6,7,40,50,55,66,79-83}$

The struggle against global warming and the efforts to 'adapt' to its inevitable escalation require a shared understanding of the problems society will be facing over the coming decades. However, this understanding must then lead to action in the form of ecobehaviors ${ }^{8488}$ (eco-decision-making, ecomanagement) adopted in a responsible and sustainable manner by a maximum of individuals and groups (ecocompetency). No one today can escape global warming and its challenges. ${ }^{89}$ Public health, ${ }^{66-68,74,80,90-93}$ along with other sectors, ${ }^{94}$ must respond to these challenges by continually updating its database and professional competences, as well as developing new ways of thinking, communicating, and acting..$^{73}$

Thus, at the dawn of the 21 st century, public health professionals in Quebec, Canada, and elsewhere in the world are faced with a double challenge (Figure1):

- Part 1 - Transdisciplinary KT (the utilization/integration/ transfer/implementation of knowledge)

- Part 2 - 'Adaptation' to climate change ${ }^{36,37}$

Before proposing a program to meet this crosscutting challenge, we will examine the specific demands associated with each of the aforementioned parts (Part 1 and Part 2), which will in turn allow us to set forth the research chair's vision and mission, as well as the objectives of its programmatic research axes. Again, our working hypothesis concerning KT is that there is a codependent relationship ${ }^{95-97}$ between 'adaptation' measures (that seek to reduce the impact of climate change on nature and human society) and mitigation measures (that target the causes of climate change and seek to reduce the greenhouse gas anthropogenic emission).

Some sectors particularly concerned with 'adaptation' are health, the environment, and public security. Those sectors more particularly concerned with 'mitigation' are energy, transportation, municipal government, and agriculture. Although adaptation is a characteristic, even inevitable, option for public health, this sector must imperatively target effect reduction in order to tackle the problem at its root. 


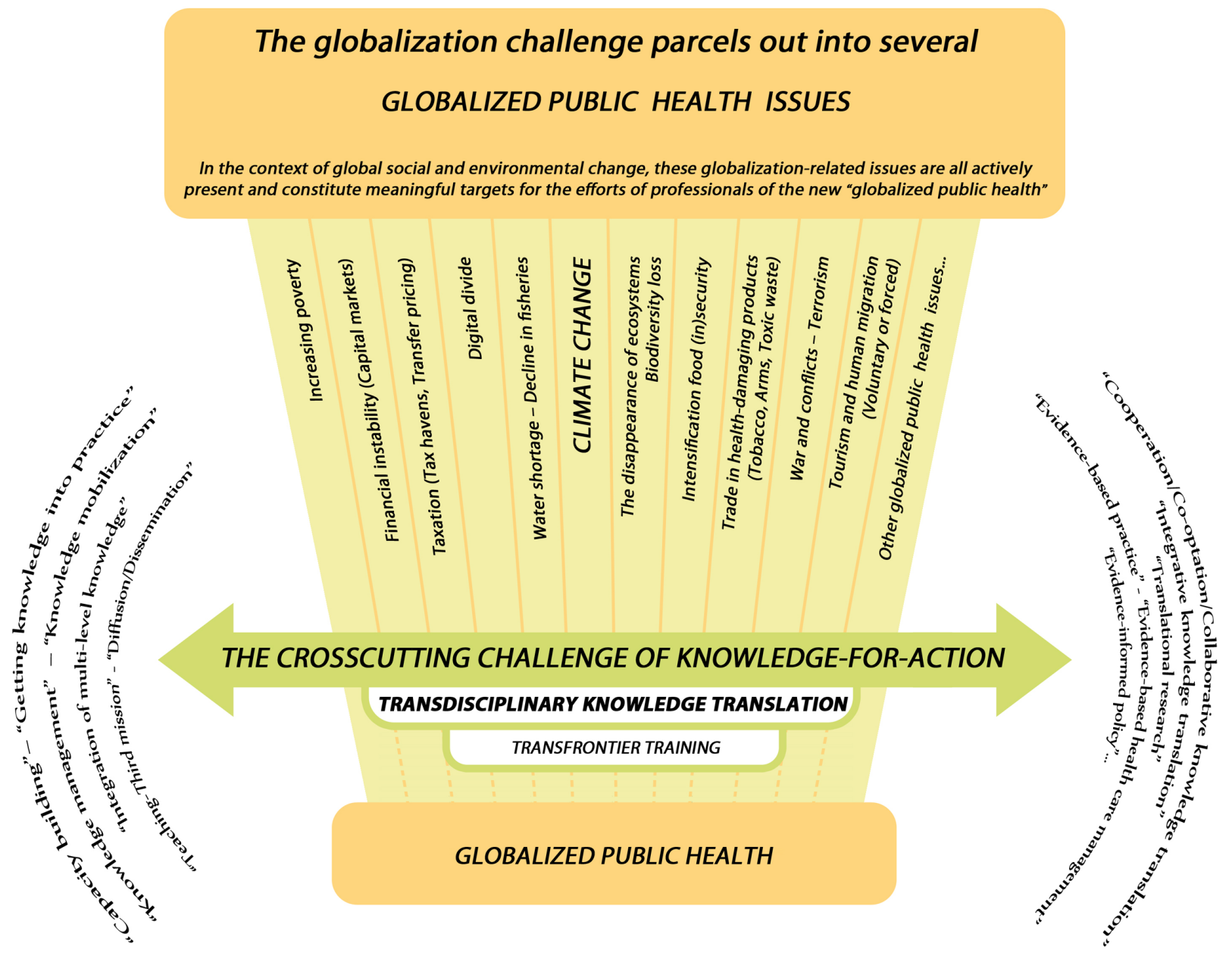

Figure I Transdisciplinary knowledge-for-action: A crosscutting challenge in globalized public health.

This program of KT in the face of climate change has, then, the global objective of supporting the action (ecodecisionmaking, ecointervention, and ecomanagement) of certain targeted groups (managers, deciders, clinicians, public health professionals, external partners, community workers, medias, and general public). As a function of each group's specific needs, this support could take many forms: communicating new knowledge, providing general information, increasing awareness of other cultural values, promoting change in the public's perception of climate change, modifying professional practice, enlightening decision making, and developing new professional competencies in climatic health.

\section{Specific and general contextual determinants of the program The challenge of KT in Quebec and Canada (general context)}

The issue of the diffusion and utilization of research results as well as the more general question of knowledge transfer preoccupy both the international scientific community and the clinical and management professional community. Some consider themselves to be 'doing' knowledge transfer when they publish their studies or disseminate practical manuals. Other professionals such as clinicians or managers attempt to integrate concepts:

- Evidence-based medicine, concrete application of research results (getting research into practice), and 'best practice ${ }^{98-102}$

- Clinical governance and improvement of health care ${ }^{103-105}$

- 'Integrated' patient care ${ }^{106}$

- 'Shared' care (shared decision making) ${ }^{107-109}$

- Knowledge management ${ }^{110-114}$

- Organizational learning and knowledge sharing within communities of practitioners ${ }^{115-121}$

Are all of these examples of 'knowledge transfer?' And do concepts such as 'transfer,' 'application,' 'diffusion,' 'dissemination,' 'utilization,' 'exchange,' and 'sharing' of knowledge mean the same thing? All of these concepts issue from the same culture of evidence-based decision making, but each has a precise meaning as well as a conceptual allegiance to one or another approach. ${ }^{11-13,122-126}$ Faced with 
this conceptual plurality, which concept should we chose and which should be the preferred approach in the chair's program?

Over the last decade, various actors within Quebec and Canada have promoted a professional culture of evidencebased decision making. ${ }^{127}$

- Since 1997-1998, the National Forum on Health has established the development of this culture as one of the main health sector objectives for the 21 st century.

- At the same time, the Canadian Health Services Research Foundation (CHSRF) has made a priority of evidencebased decision making in the organization, management, and delivery of health services.

- The same importance was granted to evidence-based management within the Executive Training for Research Applications (EXTRA) program, created at the beginning of this century by the CHSRF in partnership with three institutions: the Canadian College of Health Services Directors, the Canadian Medical Association, and the Canadian Nurses Association. The goal of the EXTRA program is to acquaint deciders with research within a culture of evidence-based decision making. ${ }^{128}$

- Finally, many professional organizations (nurses, doctors, and other health professionals) at provincial and national levels have adopted an evidence-based approach during this same period.

This 'evidence-based' culture includes:

1. 'Evidence-based medicine,' appearing in the early 1990s, but rapidly expanding to 'evidence-based practice' across clinical health sciences (namely, evidence-based nursing, evidence-based social work, etc) ${ }^{30,126,129-132}$

2. 'Evidence-based public health,' including 'evidencebased health promotion' that particularly involves public health professionals confronted with the development of complex interventions, implementing, and evaluating new programs ${ }^{133-139}$

3. 'Evidence-based health care management' that involves clinical administrators and public health managers ${ }^{140}$

4. All of these evidence-based components call for an 'overall evidence-based health care organization' ${ }^{141,142}$ that will be capable of formulating 'evidence-informed policies' $34,143,144$

Canada's current position as one of the world leaders in research on KT is no accident. ${ }^{18,127}$ From the end of the 20th century, the Canadian position has clearly been to apply research results at all levels of health care and health care management: micro (clinical), meso (management), and macro (political). ${ }^{18,127}$ Since the end of the 1980s, the Canadian health system, along with many health systems around the developed world, has entered a deepening structural crisis involving aging populations, national budget limitations, an exponentially growing research literature, and the arrival of new, expensive medical technologies. In spite of this deepening crisis, Canada has remained faithful to its commitment to apply research results to decisional processes as a privileged means for providing equitable health care to her citizens. ${ }^{145}$ In the context of a knowledge economy, ${ }^{146,147}$ the adoption of a knowledge management strategy followed by research-informed decision making in clinical, management, and political environments has been placed at the heart of policies targeting the Canadian objectives of equity and effectiveness of the health system. ${ }^{144,148-}$ ${ }^{151}$ However, in spite of these efforts to promote utilization of evidence, there is a significant gap between knowledge produced and made public and expected changes in behavior and practice on the part of deciders (knowledge users) within the health system. ${ }^{152-154}$ This 'know-do' gap has been held responsible for subperformance of health systems and growing disparities/inequities in health care. ${ }^{124,150,155-158}$ These negative consequences are all the more regrettable because they could have been avoided if the available research results had been applied. ${ }^{137,138}$

Unfortunately, there appears to be nothing linear or automatic about the effective utilization of research results that become available to health system professionals. Instead, we see a complex, dynamic, and iterative process that involves various actors with their specific needs, interacting in an asymmetrical information context that includes the constraints inherent in the results themselves as well as the specific constraints characteristic of the targeted environments. ${ }^{123,144,159}$ Because of this complexity, effective KT becomes a process involving a multitude of actors (producers and users of knowledge) interacting at several levels. We can begin to speak of an 'exchange' of knowledge and, consequently, of 'collaborative' strategies that can initiate or facilitate dynamic and multidirectional communications between knowledge producers and potential users. In recent years, these interactions and collaborative strategies have been successively structured in a series of knowledge use models (science push, demand, problem solving, enlightenment, strategic, and deliberative). ${ }^{30,160-164}$ Depending on the model, research results could impact through 'instrumental' use (ie, the direct impact of research results on practice and policy), 'conceptual' use (ie, the impact of research results on thinking and understanding), and 'symbolic use' (ie, the use of research results as a political tool to legitimatize opposition or practice).${ }^{164-167}$ Development of these models has led to the progressive emergence of 
an entire research area, which was first called 'transfer of research results' in Quebec, and later termed 'transfer of knowledge,' then 'KT' by the Canadian Institutes of Health Research (CIHR). ${ }^{11,123,124,168}$ As for 'knowledge transfer,' the CIHR uses this term to refer to the transformation of tacit knowledge into explicit knowledge. ${ }^{123,124}$

Over recent years, KT has evolved from a field of study $^{151}$ into a dynamic research area with its own limits, subdivisions, and challenges. ${ }^{11,30,38,123,126}$ Today, one speaks not only of a 'practice' of KT comprising the development of a fundamental knowledge-to-action process, ${ }^{a}$ along with several typical knowledge application 'activities,' but also me speaks of a 'science' of KT, characteristic of a major research area. ${ }^{123,168} \mathrm{KT}$ research concentrates on the scientific study of the determinants, processes, and outcomes of KT. The overall goal is to foster the development of a theoretical foundation and empirical database that can be generalized to optimize the KT process and its knowledge application activities. As other worldwide scientists, many Canadian scientists have put KT research on the map as a new domain of interdisciplinary health research, at the junction of behavioral sciences (social psychology), clinical sciences (medicine and nursing), organizational and managerial sciences (health administration), and research on health services. ${ }^{172}$

This new domain now includes nine ${ }^{\mathrm{b}}$ subdivisions. ${ }^{159,168}$ Each confronts specific challenges ${ }^{38,168}$ (terminological, conceptual, methodological, and evaluation challenges), and can be viewed from two main perspectives.

The first perspective is a process-centered view on the transfer of technologies ${ }^{173-178}$ and/or transfer of innovations. ${ }^{179-}$ ${ }^{184}$ It permits identification of the successive steps in the

\footnotetext{
${ }^{a}$ Knowledge-to-action (KT) is an interactive, dynamic, and complex process. ${ }^{123,168,169}$ It is interactive in the sense that it occurs within a system of exchanges among producers and users of knowledge, and oftentimes includes other actors. It is dynamic in the sense that it involves a range of actions such as adoption, integration, mobilization, and use of knowledge in order to transform or concretely apply knowledge toward better practice and exemplary actions. Finally, KT is complex, implying as it does: 1) identification of the know-do gap within each problem area, and identification of existing knowledge and knowledge needs for various targeted groups; 2) examination of knowledge in order to adapt it to local needs; 3) acquaintance with all actors involved, and an understanding of their interactions; 4) familiarity with the local context within which knowledge will be used, shared, or transformed; 5) identification of obstacles and facilitating factors to KT; 6 ) development of strategies as well as professional activities through which knowledge can be assimilated and integrated by concerned local actors, leading ultimately to modified perceptions and practices; and 7) evaluation of the results of the KT process: was the transferred knowledge accessible, understood, and used? Did the targeted group demonstrate changes in understanding, attitudes, and professional practice? Did the KT process demonstrate sustainability, innovation, and did it lead to complex collaboration? ${ }^{170,171}$
}

KT process as well as confirmation of its interactive character. ${ }^{144,181,185-195}$ Among the various process-centered conceptual frameworks, ${ }^{30,194-201}$ the Canadian school $^{\mathrm{c}}$ generally favors Graham's knowledge-to-action process framework $^{124,201}$ (this model has been modified in our program to become transdisciplinary).

The second perspective is a determinants'-oriented perspective. Studies of organizational determinants have targeted either public organizations such as administrative institutions, ${ }^{202,203}$ research centers, and universities, ${ }^{144,204}$ or private organizations such as industries. ${ }^{205}$ Studies of individual determinants have targeted actors up- or downstream from KT: deciders, ${ }^{206-209}$ managers, professionals, ${ }^{210,211}$ knowledge brokers, ${ }^{212}$ researchers, ${ }^{159,189,212,213}$ and the general population. ${ }^{213}$ In our program, we study determinants related to the following: 1) actors, 2) knowledge, 3) organizational and contextual ${ }^{159}$ characteristics, and 4) the 18-odd features that characterize complex collaborations and 'transdisciplinary' KT research and practice. ${ }^{214}$

\section{The challenge of climate change in Quebec and Canada (specific context)}

For Quebec, Canada, and other societies, today's indisputable global warming will bring not only an increase in average temperatures, but also a rise in sea level, and increased risk for extreme climatic and meteorological events. ${ }^{39}$ Although climatic variability has always been part of our world, a major, qualitative change has occurred over the last 50 years. Human activity, notably in the increased use of fossil fuels and in new techniques of agricultural exploitation, has generated the major ${ }^{50}$ contribution to the average temperature increase observed worldwide..$^{39,50,215,216}$ Along with other human-driven global environmental changes, climate change constitutes a menace for the entire ecosystem, and therefore for human health. ${ }^{215-219}$

\footnotetext{
${ }^{\mathrm{b}}$ 1) Knowledge synthesis (to identify the knowledge for KT); 2) Research into the evolution of and critical discourse around research evidence; 3) Research into knowledge retrieval, evaluation, and knowledge management infrastructure; 4) Identification of knowledge to action gaps; 5) Development of methods to assess barriers and facilitators to KT; 6) Development of methods for optimizing KT strategies; 7) Evaluations of the effectiveness and efficiency of KT strategies; 8) Development of KT theory; and 9) Development of KT research methods. ${ }^{168}$

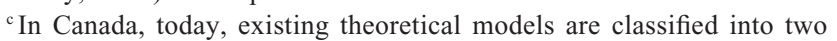
general approaches: 1) the 'classical' models' approach often seen today as too descriptive and prescriptive, historically inspired by psychological theories of cognitive change, educational theories, organizational theories, and theories of 'quality improvement;' and 2) the 'planned action' approach, currently favored in Canada by authors such as Graham and Tetroe ${ }^{201}$ and considered as an approach that 'causes change'.
} 
In spite of geographical and demographic vulnerabilities, no region on earth escapes this environmental menace $:^{38,43,44,46,220-222}$ it is a planetary phenomenon with complex, cascaded impacts on human and ecological systems and whose effects can be direct and indirect, subtle, or sudden. These effects act simultaneously on three key elements: social groups and populations, the built and natural environment, and socioeconomic activities/sectors (and in particular, the health services/sector). ${ }^{40}$

For the public health field, global warming is creating a complex, critical, and worrisome situation that poses challenges to the fundamental mission of developing, promoting, and applying new knowledge and knowhow. ${ }^{37,38,66-68,74,80,83,90-93}$ It is important that public health providers begin to take on a leading role in the development of knowledge, in the transfer of learning, and in training and education not only for public health professionals (who must today begin to develop new competencies) but also for working people, social groups, and populations. Numerous studies have clearly demonstrated the negative repercussions of climate change at regional, national, and global levels. ${ }^{54-56,61-67}$ Climate, as a macrodeterminant of health, is itself linked to other macrodeterminants of health. ${ }^{223}$ Consequently, climate change influences health via complex, interrelated pathways that can be direct or indirect. ${ }^{216}$

In Quebec and in Canada, researchers have noted six health risks stemming from climate change; these risks impact public health through eight types of effects. The six risks are as follows:

1. Extreme temperatures (heat waves)

2. Extreme weather conditions with their concomitant socioeconomic consequences

3. Air quality (eg, smog)

4. Water and food contamination

5. Infectious disease transmission via insects, ticks, and rodents

6. Increased exposure to UV rays ${ }^{37,55,56,224}$

The eight correlated effects on health are as follows:

1. Heat-related mortality and morbidity

2. Consequences of extreme weather conditions (eg, posttraumatic stress disorder after exposure to climatic catastrophes)

3. Effects of atmospheric pollution (eg, asthma, cancer, and cardiovascular illnesses), particularly apparent in North America $^{49,216}$

4. Consequences of food and water contamination (eg, diarrhea and food poisoning)
5. Zoonotic diseases and vector transmission (the first case of hantavirus-induced lung infection in Quebec was reported in $2005^{225}$ )

6. Consequences of increased UV (eg, skin cancer, cataracts, and weakening of immune systems)

7. Consequences for particularly vulnerable groups in cities and rural environments ${ }^{226,227}$

8. Socioeconomic consequences (eg, loss of productivity and revenue $)^{228}$

All of these effects impact in a differential way, as individuals with limited resources, in poor health, seniors and young children are generally more at risk. ${ }^{43,228,229}$ For example, Bélanger et al found that certain group vulnerabilities exacerbated the impact of heat waves (isolation of seniors, reduced mobility, poverty, presence of chronic neurological problems, residence in apartment blocks, and limited access to recreational facilities during a heat wave). ${ }^{230}$ Vulnerabilities to climatic health risks that threaten different systems (individuals, populations, and institutions) induce complex and diversified impacts depending on: 1) the nature of the 'external factor' or exposure to climate change (ie, heat wave), 2) the 'internal sensitivity of the system' to this exposure's impacts, and 3) the internal 'system's adaptive capacity'. Although many studies have described interactions of these three variables, few have offered the possibility of a real integration, ${ }^{231}$ because of the daunting challenge of dealing with a concept like 'vulnerability,' whose nature and conceptualization vary across contexts like climatology, ecology, social science, and public health. ${ }^{232,233}$ As for 'adaptive capacity,' not only is it difficult to quantify, but the factors that can improve or diminish adaptive capacity also vary across time and geographical contexts. ${ }^{234-236}$ For instance, 'adaptive capacity' is considerably affected by access to technologies, economic resources, renewed learning and professional ecocompetencies, the state of public health infrastructures, social networks, and general health status of the population. ${ }^{237,238}$ At the individual level, 'adaptive capacity' is influenced by several determinants such as individual health, education (information, aptitudes, and learning), socioeconomic level, available social networks, and access to resources.

Today, systems such as public health have made a priority of improving their adaptive capacity. ${ }^{239}$ Numerous actors (individuals, organizations, industries, and governments) work toward improving adaptive capacity, even to the point of choosing and applying specific measures to this end. ${ }^{\mathrm{d}}$ Today, governments can significantly contribute by providing 
information and tools, as well as by structuring interventions that can improve adaptive capacity. ${ }^{240-242}$

The United Nations Framework Convention on Climate Change explicitly calls for an improvement of adaptive capacity. However, today in Canada, ${ }^{44}$ as in other countries, attention granted to 'adaptive capacity' often takes the form of reactions to specific, urgent situations, given the socioeconomic burden ${ }^{243-246}$ already present and anticipated in the future as well as increasing mortality and morbidity rates $^{\mathrm{f}}$ (linked with heat waves, skin cancer, cardiovascular, respiratory, vectorial, renal, hepatic, neurological, and mental illnesses). ${ }^{247-250}$ Recent extreme events in Europe (eg, heat wave of 2003), ${ }^{251-253}$ the United States (eg, hurricane Katrina in 2005), ${ }^{254}$ and Canada (eg, the ice storm of 1998) have all shown how even modern developed societies can be overwhelmed, thus emphasizing the critical importance of assessing vulnerabilities $\mathrm{g}$ as well as selecting effective adaptation measures. 'Adaptation' programs on climate change are codependent with 'mitigation' policies, and the two complement each other.

As noted in the last National Canadian Evaluation, Quebec has not been idle in responding to climate change. Since 1992, Quebec has respected the principles set forth in the United Nations Framework Convention on climate change, and has consequently carried out various initiatives, such as the application of the 2006-2012 Action Plan concerning climate change, as well as passing a law concerning sustainable development. ${ }^{41,256}$ This same period has witnessed the development of the Ouranos Consortium, composed of more than 150 researchers. ${ }^{36,37,77,257}$ This consortium is financed by several Canadian ministries, and is an integral part of Canada/Quebec's strategy of adaptation to climate change. ${ }^{258-261}$ Ouranos participates in the elaboration of a Canadian climate model, high-resolution

\footnotetext{
${ }^{\mathrm{d}}$ These measures take many distinct forms, and can include behavioral changes, operational modifications, technological interventions, legislation, updating of professional practice, and investment planning. ${ }^{233}$

${ }^{\mathrm{e}}$ In terms of the United Nations Framework Convention on Climate Change, participating nations must facilitate adaptation by attenuating ongoing impacts, reducing sensitivity and exposure to climate dangers, and increasing resistance to stressful climatic and nonclimatic factors (strengthening adaptive capacity).

${ }^{\mathrm{f}}$ On the basis of the best-known available data, climate change is estimated to have caused 150,000 deaths and 5.5 million DALY (disability-adjusted life years) in the year 2000 .

${ }^{\mathrm{g}}$ There are several types of adaptation. ${ }^{234}$ Adaptive capacity includes anticipatory or preventive measures (before observed impacts) and reactive or corrective measures (after impacts). Both can be planned (products of political decision), but reactive measures can also be unplanned, spontaneous, after-the-fact. Planned adaptation consists of four phases: 1) information gathering and awareness raising; 2 ) conception and planning; 3) putting into practice; and 4) surveillance and evaluation. ${ }^{255}$
}

regional models to study the impacts of climate change. ${ }^{37}$ In addition, Ouranos has developed public health programs in collaboration with Health Canada, the Ministry of Health and Social Services of Quebec, and the National Public Health Institute of Quebec.

Quebec, then, already acts proactively with respect to climate-related health risks, as shown by actions related to zoonoses, vector-borne illnesses, climatic catastrophes, heat waves, and air and water pollution. ${ }^{230,262-270}$ However, despite Quebec's vigorous actions in implementing adaptation measures, Bourque has found the province lacking in the application of the strategic priority of "communicating and informing, in order to increase awareness and change behaviors" (p. 217, translated). ${ }^{40}$ Gosselin also calls for efforts to increase awareness of climate change in the general population, as well as a more effective application of available knowledge - "it is time that research and development activities, until now confined to the Ouranos consortium, begin to be more available in the field" (p. 320, translated). ${ }^{55}$

\section{Characteristics of the proposed program}

Quebec, along with the rest of the planet, faces major challenges in terms of effectively managing climate-associated risks as well as strengthening the society's adaptive capacity. ${ }^{36,37}$ These challenges are as immense as they are uncertain, but their complexity should not and cannot prevent the public health field from acting. ${ }^{67-70,73-80,91-93,271,272}$ Continuing obstacles to 'adaptation to climate change' include lack of awareness of health risks, unequal access to protective measures, limited awareness of the best adaptive actions, lack of collaboration between levels of government, lack of integration of knowledge between sectors concerned by adaptation, and lack of a general program of preparation for natural catastrophes (for both primary and secondary health services). In addition, serious shortcomings have been identified in the education of the general public and of future health care professionals. Several authors have noted lack of efforts at national and international levels for education and awareness raising important issues pertaining to climate-related risk prevention or reduction. ${ }^{43,55,66,71,264,265}$ Pointing out the multiple actors that must be reached (individuals, groups, as well as provincial, national, and international actors), public heath scientists have stressed the need to develop strategies of KT adapted to the levels and needs of targeted actors, taking into account the different levels of knowledge at stake. ${ }^{71,72,272}$ Application of these strategies must not be 'security oriented,' but rather be 'public health oriented,' according to these authors. ${ }^{272}$ 
Quebec does not yet have a structured, coherent program for public health professionals and practitioners addressing the prevention and/or treatment of the physical, psychosocial, and psychological effects of climate change. Furthermore, Quebec does not have a clearly defined process for the application/implementation of available knowledge pertinent to climate change attenuation and the public health system's adaptation to climate change (it must be said that no model for such a 'knowledge-for-adaptive-action' process exists anywhere today in the international scientific literature).

Returning now to our challenges concerning KT on climate change, and taking into account what has been mentioned above, we can now set forth key elements of the research chair's program:

- This program's major theme will be the 'science' and the 'practice' of KT, KT being conceived in the double perspective of process and determinants; this program will touch directly or indirectly five of the nine subdivisions of KT research, and will attempt to respond to three of the four challenges faced by this emerging field today.

- This program will respond to the need to promote scientific and traditional climatic health-related knowledge and to the need to apply this knowledge in an integrated, cohesive manner outside the milieu in which this knowledge was generated, all the while favoring interactions between producers and users of this knowledge.

- This program will respond to the need to train, educate, and increase awareness in several targeted groups, to develop their individual and collective competencies concerning climatic health or to develop the application of these competencies, while keeping in mind the possible need to renew public health knowledge in the context of global climate change.

- The chair is thus primarily oriented toward the training of potential key actors in climate change adaptation as well as to public education, and secondly oriented toward research on the implementation of knowledge pertinent to public health systems' adaptation to climate change.

The chair will be a Quebec partnership/collaborative ${ }^{\mathrm{h}}$ chair of advanced training, dedicated to the integration and implementation of knowledge relevant to helping health services adapt to climate change. The chair will offer strategic support to Ouranos. In addition, its interventions will be in conformity with Article 6 of the United Nations Framework Convention on Climate Change, and also conform with 'Theme 6' of Quebec's 2006-2012 Action Plan for climate changes (local Agenda 21).
With a continuing relevance perspective, the chair's activities will abide, at both national and global levels, by the overall framework of the United Nations convention, and will aim to promote a strong and fair post-Kyoto agreement that would foster an objectively equitable and durable healthy climate. The scientific activities of the chair can be summarized under the following three headings:

1. Training and education of professionals and practitioners of public health/mental health, as well as of public service managers

2. Increasing awareness of the general public (and working population)

3. Research on the processes and determinants of KT and on knowledge-integration programs: their results, sustainability, and functional optimization.

\section{A partnership/collaborative research chair as a leader in training and communication, and a laboratory for studying climatic health KT A 'transfrontier' vision}

The chair is 'transfrontier,' promoting the innoversity ${ }^{273}$ (the dynamic relationship between innovation and diversity) and complex collaboration ${ }^{170,171}$ essential for establishing 'transfrontier KT' for an evidence-based, equitable, and sustainable climatic health.

The 'transfrontier' aspect of this vision ${ }^{259}$ refers to a KT that would ideally be:

- Transsectoral - the program seeks to transcend hermetic sectoral compartmentalization of knowledge among key actors for adaptation.

- Transdisciplinary ${ }^{\mathrm{i}}$ - the program seeks to break down disciplinary barriers (eg, clinical sciences, public health science, social sciences (eg, communication sciences, anthropology, and ecology), cognitive engineering, and climate science) and exclusionary schools of thought between key actors.

- Transnational - the program seeks to transcend spatial boundaries between agents as well as spatiotemporal boundaries between their knowledge bases.

- Transinstitutional - the program seeks to transcend institutional boundaries between agents, in terms of institutional cultures, silos, practices, as well as divergent stakes, interests, and programs.

\footnotetext{
${ }^{\mathrm{h}}$ Université de Montréal (Département de psychiatrie; Centre de recherche Fernand-Seguin de l'Hôpital Louis-H Lafontaine) and Institut national de santé publique du Québec (Canada).
} 
- Transcognitive - the program seeks to transcend the cognitive forms that characterize various disciplines, which may facilitate work and communication within a discipline but render it less accessible to other specialists, as well as to transcend the various supports, media, and practices related to these disciplines.

- Trans-knowledge level - the program seeks to integrate the various levels of knowledge ('micro' level or individual level, 'meso' level or team level/unit level, 'macro' level or organization level/policy level).

- Transcultural - the program seeks to transcend cultural and ethnic boundaries by promoting local cultures of contributing agents (eg, traditional knowledge and practices), mobilizing, and integrating them without excluding their particularities.

\section{Mission, general objectives, and programmatic axes}

In collaboration with its partners, the research chair's mission is to accomplish the following:

- Contribute to scientific progress of 'knowledge-for-adaptive actions,' and to the practice/science of KT related to the adaptation of public health and the public sector to climate change, by developing a 'transfrontier KT' approach, which implies studying KT determinants and KT programs optimization in order to strengthen the public health systems' adaptive capacities to climate change

- Support a deeper understanding of the challenges of adaptive management of climate change by:

- Contributing to the development of competencies in climate-influenced health sciences and/or the communication of knowledge to public health practitioners and to public sector managers

- Contributing to public awareness of the importance of climate change for health

- Contributing to the updating of existing training programs in public health and public administration, in the context of globalization, of changes in the public health sector, and in the changing learning approach $^{275}$

${ }^{\mathrm{i}}$ Transdisciplinarity as a form of knowledge translation research is driven by the need to solve problems of the lifeworld. By transcending disciplinary paradigms, transdisciplinary knowledge translation research is challenged by the following requirements: to grasp the complexity of the problems, to take into account the diversity of scientific and societal views of these problems, to link abstract and case-specific knowledge, and to constitute knowledge with a focus on problem solving for what is perceived to be the common good. (p. 19) 774
- Innovate conceptually in studying, developing, and communicating the concepts of 'evidence-based climatic health' (santé climatique factuelle in French), 'climatic stress,' 'climatic trauma,' and 'climatic mental health' (santé mentale climatique in French), at a national and international level

- Facilitate individual and collective partnerships that cross geographic, disciplinary, sectoral, and even cognitive boundaries, in order to favor more effective responses to climate change and to KT related to the major contemporary issues (globalization, sustainable development, and transfrontier education; ecolearning and ecocompetencies in public health; and transdisciplinarity in KT research)

The general objectives of this transfrontier knowledgefor-adaptive-action program in climatic health are presented in Table 1.

The chair's program includes five major themes in training and programmatic research axes in climatic health, which are as follows:

1. Extreme weather conditions, biopsychosocial vulnerabilities, and mental health (in French: Aléas hydrométéorologiques, vulnérabilités biopsychosociales et santé mentale axis)

2. Transfrontier education, collaborative ecolearning, and collective competences in climatic health (in French: Éducation transfrontières, écoapprentissages collaboratifs, compétences collectives en santé climatique axis)

3. North-South/West-East French-speaking world and Web-hypermedia learning tools in climatic health (in French: Francophonie Nord-Sud/Est-Ouest, technopégagogies et autoformation Web-hypermédia pour la globalisation des apprentissages axis)

4. Climate, working people, and mental health (in French: Climats, travail et santé mentale axis)

5. Innovations, technologies, theories, and models in evidence-based climatic health (in French: Innovations, technologies, théories et modèles interactifs en application transfrontières des savoirs axis)

\section{Conclusion}

This article has presented the transfrontier vision of a training and research program stressing innoversity and complex collaboration. Any reader interested in discussing these issues, or in collaborating in their study, is invited to communicate with the first author. Whether you be North or South/West 
Table I General objectives of the transfrontier knowledge-for-adaptive-action training and research program

\begin{tabular}{|c|c|}
\hline Objective I & $\begin{array}{l}\text { Communicate to public health practitioners and public service managers the urgency and high priority of combating the } \\
\text { negative effects of climate change, help make them ready and able to assume their complex role in the face of the challenge of } \\
\text { understanding and fighting climate change armed with the latest pertinent knowledge }\end{array}$ \\
\hline Objective 2 & $\begin{array}{l}\text { Increase awareness among the general public, public health practitioners, and public service managers, regarding the health- } \\
\text { related impacts of climate change at the local, national, and global levels, by means of informative and knowledge-application } \\
\text { activities }\end{array}$ \\
\hline Objective 3 & $\begin{array}{l}\text { Develop and reinforce, among the general public, mental health professionals, public health practitioners, and public service } \\
\text { managers, the capacity to identify, understand, define priorities, and apply adaptive measures }\end{array}$ \\
\hline Objective 4 & $\begin{array}{l}\text { Develop an andragogy program of in-service training to provide basic, factual information on climate change to public health } \\
\text { practitioners and public service managers }\end{array}$ \\
\hline Objective 5 & $\begin{array}{l}\text { Develop and suggest addendums to existing university and college programs that are related to public health and health } \\
\text { sciences, to add pertinent elements concerning the challenges of climate change and knowledge translation }\end{array}$ \\
\hline Objective 6 & $\begin{array}{l}\text { Promote fruitful exchanges among students, researchers (in public health sciences, clinical sciences, social sciences, public } \\
\text { administration, climate science, and knowledge translation sciences), public health practitioners, and public service managers, as } \\
\text { well as the general public, on subjects related to the application of knowledge to climate-change-related challenges, namely by: } \\
\text { - Collaborating and partnering with other chairs, research centers, and external partners; } \\
\text { - Organizing 'transfrontier' events pertaining to climate health and adaptive management of climate-change-related risks; } \\
\text { - Offering research scholarships to master's and doctoral students; } \\
\text { - Welcoming sabbatical professors in health, social sciences, and public administration. }\end{array}$ \\
\hline Objective 7 & $\begin{array}{l}\text { Participate in public discussions and debates on the application of knowledge to climate change challenges in public health, } \\
\text { ecotraining in public health, and new evidence-based training programs in climatic health }\end{array}$ \\
\hline Objective 8 & $\begin{array}{l}\text { Develop a research program on the application of knowledge to climatic health, so as to } \\
\text { - Better understand the concepts, theories, and practices that underlie an effective knowledge translation, as well as a } \\
\text { transfrontier integration of knowledge pertinent to the adaptation of public health and the public sector to climate change; } \\
\text { - Better understand possible interrelations between the determinants of knowledge translation, and the determinants of the } \\
\text { public sector's adaptive capacity. }\end{array}$ \\
\hline Objective 9 & $\begin{array}{l}\text { Participate in complex collaborative research on the transfrontier application of knowledge related to public sector adaptations } \\
\text { to climate change, for example: } \\
\text { - Synthesis of knowledge and development of a theoretical model of the application of climate-change-related knowledge; } \\
\text { - Development of a technological infrastructure to facilitate the translation of climatic health knowledge; } \\
\text { - Optimization of strategies for the translation of climatic health knowledge; } \\
\text { - Evaluation of the effectiveness of climate-change-related knowledge translation strategies; } \\
\text { - Delineation and analysis of the know-do gap in climatic health; } \\
\text { - Study of the micro/macro interrelations between the determinants of knowledge translation and the vulnerabilities and } \\
\text { behavioral changes in vulnerable populations. }\end{array}$ \\
\hline
\end{tabular}

or East, an individual or an institutional actor, and regardless of your disciplinary affiliation, we hope to share with you this new vision of a transfrontier KT and education for an evidence-based, equitable, and sustainable climatic health.

\section{Acknowledgments}

Funding has been provided by the Fonds vert du gouvernement québécois (Ministère de la Santé et des Services sociaux du Québec: Thème 6 de l'Action 21 du Plan d'action 2006-2012 sur les changements climatiques).

\section{Disclosure}

The views expressed in this article are those of the authors and do not necessarily reflect the position or policy of the Quebec Ministry of Health and Social Services, the Quebec National Public Health Institute, the Canadian Consortium OURANOS (Consortium on Regional Climatology and Adaptation to Climate Change), the Fernand-Seguin
Research Center (and the Fonds de recherche en santé du Québec), the University of Montreal (Department of Psychiatry, Faculty of Medicine), or the Laval University (Faculty of Nursing).

\section{References}

1. Lee K. Globalization and Health: An Introduction. Basingstoke, UK: Palgrave Macmillan; 2003.

2. Labonte R, Schrecker T, Packer C, Runnels V, editors. Globalization and Health: Pathways, Evidence and Policy. London, UK: Routledge; 2009.

3. Organisation des Nations Unies. Objectifs du Millénaire pour le développement. New York: ONU. Available from: http://www.un.org/french/ millenniumgoals/index/shtml. Accessed Sep 172009.

4. Lapaige V. La santé publique globalisée. Saint-Nicolas, QC: Presses de l’Université Laval; 2009.

5. Ciliska D, Tomas $\mathrm{H}$, Buffet $\mathrm{C}$. Introduction au concept de santé publique fondée sur les données probantes et recueil d'outils d'évaluation critique pour la pratique en santé publique. Hamilton, ON: National Collaborating Centre for Methods and Tools (NCCMT); 2008.

6. World Health Organization. Ecosystems and Human Well-being: Health Synthesis. Report of the Millennium Ecosystem Assessment. Geneva, Switzerland: WHO; 2005. 
7. Stone D. Sustainable development: convergence of public health and natural environment agendas, nationally and locally. Public Health. 2006;120(12):1110-1113.

8. Labonte R, Torgerson R. A Critical Review of Frameworks Linking Globalization and Health. Geneva, Switzerland: World Health Organization; 2003.

9. Lee K. Health Impacts of Globalization: Towards a Global Governance. Basingstoke, UK: Palgrave Macmillan; 2003.

10. Commission on Social Determinants of Health. Closing the Gap in a Generation: Health Equity Through Action on the Social Determinants of Health. Final Report of the CSHH. Geneva, Switzerland: World Health Organization; 2008.

11. Straus SE, Tetroe J, Graham ID. Knowledge to action: what it is and what it isn't. In: Straus S, Tetroe J, Graham ID, editors. Knowledge Translation in Health Care. Moving from Evidence to Practice. Chichester, UK: John Wiley and Sons, Wiley-Blackwell; 2009:3-9.

12. Ottoson JM, Hawe P, editors. Knowledge Utilization, Diffusion, Implementation, Transfer, and Translation: Implications for Evaluation. New Directions for Evaluation. Vol. 124. Hoboken, NJ: John Wiley and Sons; 2010.

13. Bammer G. Integration and implementation sciences: building a new specialization. Ecol Soc. 2005;10(2):6. Available from: http://www ecologyandsociety.org/vo/vol10/iss2/art6/. Accessed Jan 102010.

14. Lapaige V. Le Québec face au défi croisé de l'application des savoirs en santé climatique. Glob Health Promot. 2010;17(4).

15. Lauder H, Brown P, Dillabough J-A, Halsey AH. Education, Globalization, and Social Change. New York, NY: Oxford University Press 2006.

16. Carré P. L'apprenance: vers un nouveau rapport au savoir. Paris: Dunod; 2005.

17. Lüdeke MKB, Petschel-Held G, Kemp R. Syndromes of global change. The first panoramic view. GAIA. 2004;13(1):42-49.

18. Lomas J, Culyer T, McCutcheon C, McAuley L, Law S. Rapport final-Conceptualiser et regrouper les données probantes pour guider le système de santé. Ottawa, ON: Fondation canadienne de la recherche sur les services de santé (FCRSS); 2005.

19. Loibl MC. Integrating perspectives in the practice of transdisciplinary research. In: Voß J-P, Bauknecht D, Kemp R, editors. Reflexive Governance for Sustainable Development. Cheltenham, UK: Edward Elgar; 2006:294-309.

20. Ramagnino N, Verges P. Épistémologie des sciences sociales, le problème des disciplines et l'interdisciplinarité (Enseignements fondamentaux, DEA de Sociologie, Université de Provence). Anthropologie 1997-1987. 1998:7.

21. Wilson EO. Consilience. The Unity of Knowledge. London, UK: Abacus; 1998.

22. Giri AK. The calling of a creative transdisciplinarity. Futures. 2002; 34(1):103-115.

23. Bammer G. LWA Integration Symposium Participants. Guiding principles for integration in natural resource management (NRM) as a contribution to sustainability. Australas J Environ Manage. 2005;12 Suppl:S5-S7.

24. van Kerkhoff L. Integrated research: concepts of connection in environmental science and policy. Environ Sci Policy. 2005;8(5): 452-463.

25. Pohl C, van Kerkhoff L, Hirsch Hadorn G, Bammer G. Integration. In: Hirsch Hadorn G, Hoffmann-Riem H, Biber-Klemm S, et al, editors. Handbook of Transdisciplinary Research. Bern, Switzerland: Springer; 2008:411-424.

26. Higginbotham N, Albrecht G, Connor L. Health Social Science. A Transdisciplinary and Complexity Perspective. Melbourne, Australia: Oxford University Press; 2003.

27. Star SL, Griesemer JR. Institutional ecology, 'translations' and boundary objects: amateurs and professionals in Berkeley's Museum of Vertebrate Zoology, 1907-1939. Soc Stud Sci. 1989;19(3): $387-420$
28. Kessel F, Rosenfield PL, Anderson NB, editors. Expanding the Boundaries of Health and Social Sciences. Case Studies in Interdisciplinary Innovation. New York, NY: Oxford University Press; 2003.

29. Clark W, Holliday L. Linking Knowledge with Action for Sustainable Development: The Role of Program Management - Summary of a Workshop. Washington, DC: The National Academies Press; 2006.

30. Rycroft-Malone J, Bucknall T, editors. Models and Frameworks for Implementing Evidence-Based Practice. Linking Evidence to Practice. Chichester, UK: Wiley-Blackwell and Sigma Theta Tau International; 2010.

31. Francis JJ, Eccles MP, Johnston M, et al. Constructing Questionnaires Based on the Theory of Planned Behaviour: A Manual for Health Services Researchers. Newcastle, UK: Centre for Health Services Research, University of Newcastle; 2004.

32. Réseau de recherche en santé des populations du Québec. Des repères pour la recherche sur le partage des connaissances en santé des populations. Carnet-synthèse préparé par et avec la collaboration de Dagenais C, Laurendeau MC, Souffez K, Axe Partage et Utilisation des Connaissances du RRSPQ (Bergeron P, Laurendeau MC, Joubert P, Lévy J, Souffez K). Montreal, QC: Réseau de recherche en santé des populations du Québec; 2007.

33. Graham ID, Tetroe J. Whither knowledge translation: an international research agenda. Nurs Res. 2007;56 Suppl 4:S86-S88.

34. Glanz K, Rimer BK, Viswanath K, editors. Health Behavior and Health Education: Theory, Research and Practice. San Francisco, CA: JosseyBass; 2002.

35. Michie S, Johnston M, Abraham C, Lawton R, Parker D, Walker A; 'Psychological Theory' Group. Making psychological theory useful for implementing evidence based practice: a consensus approach. Qual Saf Health Care. 2005;14(1):26-33.

36. Gosselin P, Bélanger D. Recherche, impacts et adaptations de santé publique au nouveau climat du Québec. Santé Publique. 2010;22(3): 281-302.

37. Desjarlais C, Allard M, Blondot A, et al. Savoir s'adapter aux changements climatiques. Montreal, QC: Ouranos; 2010.

38. Costello A, Abbas M, Allen A, et al. Managing the health effects of climate change: Lancet and University College London Institute for Global Health Commission. Lancet. 2009;373(9676): 1693-1733.

39. Solomon S, Qin D, Manning M, et al. Climate Change 2007: The Physical Science Basis. Working Group I Contribution to the Intergovernmental Panel on Climate Change Fourth Assessment Report. Cambridge, UK: Cambridge University Press; 2007.

40. Bourque A, Simonet G. Québec. In: Lemmen DS, Warren FJ, Lacroix J, Bush E, editors. Vivre avec les changements climatiques au Canada: édition 2007. Ottawa, ON: Gouvernement du Canada; 2008 : 171-226.

41. Gouvernement du Québec, Ministère du Développement durable, de l'Environnement et des Parcs. Le Québec et les changements climatiques - Un défi pour l'avenir. Plan d'action 2006-2012. Québec (QC): Author; 2008. Available from: http://www.mddep.gouv.qc.ca/ changements/plan_action/2006-2012_fr.pdf. Accessed Aug 42009.

42. Gouvernement du Québec, Ministère du Développement durable, de l'Environnement et des Parcs. Troisième bilan de la mise en en œuvre du plan d'action 2006-2012 sur les changements climatiques. Québec, QC: Author; 2009.

43. Lemmen DS, Warren FJ, Lacroix J, Bush E. Vivre avec les changements climatiques au Canada: édition 2007. Ottawa, ON: Gouvernement du Canada; 2008

44. Gouvernement du Canada. Quatrième rapport national du Canada sur les changements climatiques: mesures prises en vertu de la Conventioncadre des Nations Unies sur les changements climatiques. Ottawa, ON: Author; 2006.

45. German Advisory Council on Global Change. Climate Protection Strategies for the 21st Century: Kyoto and Beyond-Special Report. Available from: http://www.wbgu.de/wbgu_sn2003_voll_engl.html. Accessed Sep 192009. 
46. Ministry of Environment, Sweden. The Path Towards a New International Agreement on the Earth's Climate. Available from: http:// www.regeringen.se/content/1/c6/10/33/83/27418bc4.pdf. Accessed Sep 192009.

47. Challen C. The Politics of Climate Change: Too Little, Too late. London, UK: Picnic Publishing; 2009.

48. Elliot L, Simms A, editors. Green New Deal: Joined-up Policies to Solve the Triple Crunch of the Credit Crisis, Climate Change and High Oil Prices. London, UK: New Economics Foundation; 2008.

49. Parry ML, Canziani OF, Palutikof JP, van der Linden PJ, Hanson CE. Climate Change 2007: Climate Change Impacts, Adaptation and Vulnerability. Working Group II Contribution to the Intergovernmental Panel on Climate Change Fourth Assessment Report. Cambridge, UK: Cambridge University Press; 2007.

50. Organisation des Nations unies. Convention-cadre des Nations unies sur les changements climatiques. New York. Available from: http://www. unfccc.int/resource/docs/convkp/convfr.pdf. Accessed Oct 122010.

51. Convention-cadre des Nations unies sur les changements climatiques. The Nairobi Work Program on Impacts, Vulnerability and Adaptation to Climate Change. Bonn, Germany: Secrétariat de la Convention-cadre des Nations unies sur les changements climatiques; 2007.

52. Convention-cadre des Nations unies sur les changements climatiques. Investment and Financial Flows to Address Climate Change: An Update. Bonn, Germany: Secrétariat de la Convention-cadre des Nations unies sur les changements climatiques; 2008.

53. Programme des Nations unies pour le développement. Rapport mondial sur le développement humain 2007/2008-La lutte contre le changement climatique: un impératif de solidarité humaine dans un monde divisé. New York, NY: Author. Available from: http://www.hdr.undp.org/en/ media/hdr_20072008_fr_complete.pdf. Accessed Aug 202009.

54. Doyon B, Bélanger D, Gosselin P. Effets du climat sur la mortalité au Québec méridional de 1981 à 1999 et simulations pour des scénarios climatiques futurs. Montréal (QC): Institut national de santé publique du Québec; 2006.

55. Gosselin P, Bélanger D, Doyon B. Les effets du changement climatique sur la santé au Québec. In: Séguin J, editor. Santé et changements climatiques: Évaluation des vulnérabilités et de la capacité d'adaptation au Canada. Ottawa (ON): Santé Canada; 2008:241-342.

56. Séguin J, editor. Santé et changements climatiques: Évaluation des vulnérabilités et de la capacité d'adaptation au Canada. Ottawa (ON): Santé Canada; 2008.

57. Bernier É, Gosselin P, Badard T, Bédard Y. Un outil Web géomatique innovateur pour mieux comprendre les risques pour la santé liés au climat. Québec (QC): Édition francophone du portail d'information géospatiale; 2008. Available from: http://francais.directionsmag.com/ articles.php?article_id=2868. Accessed Sep 102009

58. Bélanger D, Tairou FO, Bustinza R, Gosselin P. Proposition d'indicateurs aux fins de vigie et de surveillance des troubles de la santé lies aux vents violents. Québec, QC: Direction de la santé environnementale et de la toxicologie, Institut national de santé publique du Québec; 2010.

59. World Health Organization. Health and Climate Change: The 'Now and How' - A Policy Action Guide. Copenhagen, Denmark: WHO; 2005.

60. McMichael AJ, Campbell-Lendrum DH, Corvalan CF, et al. Climate Change and Human Health: Risks and Responses. Geneva, Switzerland: World Health Organization; 2003.

61. McMichael AJ, Friel S, Nyong A, Corvalan C. Global environment change and health: impacts, inequalities, and the health sector. BMJ. 2008;336(7637):191-194; Godlee F. Climate change: our new responsibility. BMJ. 2008;336(7659). Gill M. Why should doctors be interested in climate change. BMJ. 2008;336(7659):1506; Griffiths J, Hill A, Spilby J, Scott R. Ten practical steps for doctors to fight climate change. BMJ. 2008;336(7659): 1507.

62. St Louis ME, Hess JJ. Climate change: impacts on and implications for global health. Am J Prev Med. 2008;35(5):527-538; Am J Prev Med. 2008;35(5). Theme issue: climate change and the health of the public (17 papers). November (Guest editors: Frumkin H, McMichael AJ, Hess JJ).
63. Epstein PR. Climate change and human health. $N$ Engl J Med. 2005;353(14):1433-1436.

64. Haines A, Kovats RS, Campbell-Lendrum D, Corvalan C. Climate change and human health: impacts, vulnerability, and mitigation. Lancet. 2006;367(9528):2101-2109.

65. Epstein PR, Mills E, editors. Climate Change Futures - Health, Ecological and Economic Dimensions. Cambridge, MA: The Center for Health and the Global Environment, Harvard Medical School; 2005 .

66. Griffiths J, Rao M, Adshead F, Thorpe A, editors. The Health Practitioner's Guide to Climate Change-Diagnosis and Cure. London, UK: Earthscan; 2009.

67. Grambsch A, Menne B. Adaptation and adaptive capacity in the public health context. In: McMichael AJ, Campbell-Lendrum DH, Corvalan CF, et al. Climate Change and Human Health: Risks and Response. Geneva, Switzerland: World Health Organization; 2003:1-17.

68. Keim ME. Building human resilience: the role of public health preparedness and response as an adaptation to climate change. Am J Prev Med. 2008:35(5):508-516.

69. Menne B, Ebi K. Climate Change and Adaptation Strategies for Human Health. Darmstadt, Germany: Steinkopff Verlag; 2005.

70. Ebi KL, Smith J, Burton I, Scheraga J. Some lessons learned from public health on the process of adaptation. Mitigation Adapt Strateg Glob Change. 2006;11(3):607-620.

71. Menne B, Apfel F, Kovats S, Racioppi F, editors. Protecting Health in Europe from Climate Change. Copenhagen, Denmark: World Health Organization; 2008.

72. Organisation mondiale de la santé. Changement climatique et santé. Résolution WHA 61.19 de la 61e Assemblée mondiale de la santé (mai 2008). Available from: http://who.int/global-change/climate/EB_climate changehealth_resolution/fr/index.html. Accessed 2009 Sep 10.

73. Frumkin H, McMichael AJ. Climate change and public health: thinking, communicating, acting. Am J Prev Med. 2008;35(5):403-410.

74. Frumkin H, Hess J, Luber G, Malilay J, McGeehin M. Climate change: the public health response. Am J Public Health. 2008;98(3): 435-445.

75. Griffiths J, Stewart L. Sustainable a Healthy Future: Taking Action on Climate Change. 2nd ed. London, UK: Faculty of Public Health; 2009 .

76. Ebi KL. Public health responses to the risks of climate variability and change in the United States. J Occup Environ Med. 2009;51(1): 4-12.

77. Ouranos. S'adapter aux changements climatiques. Montréal, QC: Author; 2004. Available from: http:/www.ouranos.ca/doc/produit_f. html. Accessed Sep 172009.

78. Gosselin P. La santé. In: DesJarlais C, Bourque A, Decoste R, et al. $S$ 'adapter aux changements climatiques. Montréal (QC): Consortium Ouranos; 2004.

79. Climate Connection. Public Health Competences for Climate Change Mitigation and Adaptation. Available from: http://www.theclimateconnection.org/public-health-competences-climate-changev3. Accessed Sep 202009.

80. Spiby J. Developing competencies in environmental public health. Chemical Hazards and Poisons Report. 2006 Feb 6. Available from: http://www.hpa.org.uk/web/HPAwebFile/HPAweb_C/119947321801. Accessed Sep 102009.

81. DEFRA. A Framework for Environmental Behaviours. London (UK): Author; 2008

82. Homer-Dixon T. The Upside and Down: Catastrophe, Creativity and the Renewal of Civilization. London (UK): Souvenir Press; 2007.

83. Leonardi G. How to prepare for the health effects of climate change. In: Griffiths J, Rao M, Adshead F, Thorpe A, editors. The Health Practitioner's Guide to Climate Change-Diagnosis and Cure. London (UK): Earthscan; 2009:321-354.

84. Jackson T. The challenge of sustainable lifestyles. Chapter 4. In: State of the World 2008: Innovations for a Sustainable Economy. Washington (DC): Worldwatch Institute; 2008. 
85. DEFRA. Driving Public Behaviours for Sustainable Lifestyles. London (UK): Author; 2004. Available from: http://www.defra.gox.uk/ sustainable/government/publications/pdf/desk-research2.pdf. Accessed Aug 172009.

86. Prochaska JO, Norcross JC, DiClemente CC. Changing for Good. New York: William Morrow and Company; 1994.

87. Semenza JC, Hall DE, Wilson DJ, Bontempo BD, Sailor DJ, George LA. Public perception of climate change: voluntary mitigation and barriers to behaviour change. Am J Prev Med. 2008;35(5): 479-487.

88. Kollmuss A, Agyeman J. Mind the gap: why do people act environmentally and what are the barriers to pro-environmental behavior? Environ Educ Res. 2002;8(3):239-260.

89. CBI. Climate Change: Everyone's Business. London (UK): Author; 2007.

90. Noji EK. The Public Health Consequences of Disaster. New York: Oxford University Press; 1997.

91. Chan M. Climate Change and Health: Preparing for Unprecedented Challenges. Available from: http://www.who.int/dg/ speeches/2007/20071211_maryland/en/print.html. Accessed Jul 22009

92. Hanlon P, Carlisle S. Thesis: do we face a third revolution in human history? If so, how will public health respond? J Public Health (Oxf). 2008;30(4):355-361.

93. Gill M. Why should doctors be interested in climate change? BMJ. 2008;336(7659):1506.

94. Hale S. The New Politics of Climate Change: Why We are Failing and How We Will Succeed. London (UK): Green Alliance; 2008 .

95. Willbanks TJ. Issues in developing a capacity for integrated analysis of mitigation and adaptation. Environ Sci Pol. 2005;8(6):541-547.

96. Klein RJT, Schipper EL, Dessai S. Integrating mitigation and adaptation into climate and development policy: three research questions. Environ Sci Policy. 2005;8(6):579-588.

97. Klein RJT, Huq S, Denton F, et al. Inter-relationships between adaptation and mitigation. In: Intergovernmental Panel on Climate Change (Working Group II). Climate Change 2007: Impacts, Adaptation and Vulnerability. Cambridge (UK): Cambridge University Press; 2007: 745-777.

98. Evidence-Based Medicine Working Group. Evidence-based medicine. A new approach to teaching the practice of medicine. JAMA. 1992; 268(17):2420-2425.

99. Green ML. Evidence-based medicine training in graduate medical education: past, present, and future. J Eval Clin Pract. 2000;6(2): 121-138.

100. Greenhalgh T, Toon P, Russell J, Wong G, Plumb L, Macfarlane F. Transferability of principles of evidence based medicine to improve educational quality: systematic review and case study of an online course in primary health care. BMJ. 2003;326(7381):142-145.

101. Sackett DL, Rosenberg WMC, Muir Gray JA, Haynes RB, Richardson WS. Evidence based medicine: what it is and what it isn't. BMJ. 1996;312(7023):71-72.

102. Sackett DL, Straus SE, Richardson WS, Rosenberg W, Haynes RB. Evidence-Based Medicine: How to Practice and Teach EBM. 2nd ed. Edinburgh, London, New York, Philadelphia, St Louis, Sydney, Toronto: Churchill Livingstone; 2000.

103. Halligan A, Donaldson L. Implementing clinical governance: turning vision into reality. BMJ. 2001;322(7299):1413-1417.

104. Pickering S, Thompson J. Clinical Governance and Best Value. Meeting the Modernisation Agenda. Edinburgh, London, New York, Philadelphia, St Louis, Sydney, Toronto: Churchill Livingstone; 2003.

105. Grol R. Improving the quality of medical care: building bridges among professional pride, payer profit, and patient satisfaction. JAMA. 2001;286(20):2578-2585.

106. Schmid K, Conen D. Integrated patient pathways: 'MIPP'. A tool for quality improvement and cost management in health care. Pilot study on the pathway 'acute myocardial infarction'. Int J Health Care Qual Assur. 2005;13(2):87-92.
107. Elwyn D, Edwards A, Kinnersley P. Shared decision-making in primary care: the neglected second half of the consultation. Br J Gen Pract. 1999;49(443):477-482.

108. Légaré F. Introduction. In: Lalonde L, Légaré F, editors. Les choix en matière de santé et la participation du patient: vers une prise de décision partagée. Montréal (QC): ACFAS; 2006:5-8.

109. Sculpher M, Gafni A, Watt I. Shared treatment decision making in a collectively funded health care system: possible conflicts and some potential solutions. Soc Sci Med. 2002;54(9):1369-1377.

110. Alavi M, Leidner DE. Review: knowledge management and knowledge management systems: conceptual foundations and research issues. MIS Q. 2001;25(10):107-136.

111. Bali RK, Feng DD, Burstein F, Dwivedi AN. Introduction to the special issue on advances in clinical and health-care knowledge management IEEE Trans Inf Technol Biomed. 2005;9(2):157-161.

112. Bali RK, Dwivedi A, Naguib RN. The efficacy of knowledge management for personalised healthcare. Stud Health Technol Inform. 2005;117:104-107.

113. Bali RK, Dwivedi AN, editors. Healthcare Knowledge Management. Opportunities and Challenges. New York: Springer; 2007.

114. Guptill J. Knowledge management in health care. J Health Care Finance. 2005;31(3):10-14.

115. Brown JS, Duguid P. Organizational learning and communities of practice: toward a unified view of working, learning and innovation. Organ Sci. 1991;2(1):40-57.

116. Brown JS, Duguid P. The Social Life of Information. Boston (MA): Harvard Business School Press; 2000.

117. Cross R, Parker A, Prusak L, Borgatti S. Knowing what we know: supporting knowledge creation and sharing in social networks. Organ Dyn. 2001;30(2):100-120.

118. Davenport TH, Prusak L. Working Knowledge: How Organizations Manage What They Know. Boston (MA): Harvard Business School Press; 1998.

119. Hildreth P, Kimble C. Knowledge Networks: Innovation Through Communities of Practice. London (UK): Idea Group; 2004.

120. Huysman M, de Wit D. Knowledge Sharing in Practice. Dordrecht (The Netherlands): Kluwer Academic Publishers; 2002.

121. Wenger E. Communities of Practice: Learning, Meaning and Identity. Cambridge (MA): Cambridge University Press; 1998.

122. Estabrooks CA, Thompson DS, Lovely JJ, Hofmeyer A. A guide to knowledge translation theory. J Contin Educ Health Prof. 2006;26(1):25-36.

123. Graham ID. Knowledge translation at CIHR (Canadian Institutes of Health Research). CIHR IHSPR-IPPH 7th Annual Summer, 'Innovation in knowledge translation research and knowledge translation', NAV Canada Training and Conference Centre; 2008 Jun 22-25; Cornwall, Ontario.

124. Graham ID, Logan J, Harrison MB, et al. Lost in knowledge translation: time for a map? J Contin Educ Health Prof. 2006;26(1):13-24.

125. Straus SE, Graham ID, Mazmanian PE. Knowledge translation: resolving the confusion. J Contin Educ Health Prof. 2006;26(1):3-4.

126. Bick D, Graham ID, editors. Evaluating the Impact of Implementing Evidence-Based Practice. Chichester (UK): Wiley-Blackwell and Sigma Theta Tau International; 2010.

127. National Forum on Health. Creating a Culture of Evidence-Based Decision Making in Health. Ottawa (ON): Health Canada Publications. Available from: http://www.hc-sc.gc.ca/english/care/health_forum/ forum_e.htm. Accessed Dec 32008.

128. FORCES. Formation en utilisation de la recherche pour cadres qui exercent dans la santé (FORCES). Proposition de programme: conception et evolution. Rapport final du Groupe de travail sur la conception. Ottawa $(\mathrm{ON})$ : Fondation canadienne de la recherche sur les services de santé; 2003.

129. DiCenso A, Cullum N, Ciliska D. Implementing evidence-based nursing: some misconceptions (editorial). Evid Based Nurs. 1998;1:38-40.

130. Guyatt GH, Meade MO, Jaeschke RZ, Cook DJ, Haynes RB. Practitioners of evidence based care. BMJ. 2000;320:954-955. 
131. Rycroft-Malone J. Theory and knowledge translation: setting some coordinates [Comment]. Nurs Res. 2007;56 Suppl 4: S78-S85.

132. Trinder L, Reynolds S, editors. Evidence-Based Practice: A Critical Appraisal. Oxford (UK): Oxford, Blackwell Scientific; 2000.

133. Brownson RC, Baker EA, Leet TL, Gillepsie KN. Evidence-Based Public Health. New York: Oxford University Press; 2003.

134. Gray M. Evidence-Based Healthcare and Public Health. How to Make Decisions About Health Services and Public Health. 3rd ed. Edinburgh, London, New York, Philadelphia, St Louis, Sydney, Toronto: Churchill Livingstone; 2009.

135. Kelly M, Bonnefoy J, Morgan A, et al. The Development of Evidence Base About the Social Determinants of Health. World Health Organization Commission on Social Determinants of Health, Measurement and Evidence Knowledge Network; 2006.

136. McQueen DV. Strengthening the evidence base for health promotion. Health Promot Int. 2001;16(3):261-268.

137. Nutbeam $D$. The challenge to provide 'evidence' in health promotion (editorial). Health Promot Int. 1999;14(2):99-101.

138. Rychetnik L, Wise M. Advocating evidence-based health promotion: reflections and a way forward. Health Promot Int. 2004;19(2): 247-257.

139. Ziglio E. How to move towards evidence-based health promotion interventions. Promot Educ. 1997;4(2):29-33.

140. Lapaige V. Evidence-based decision-making within the context of globalization: A 'Why-What-How' for leaders and managers of health care organizations. Risk Manage Health Care Policy. 2009;2:35-46. Available from: http://www.dovepress.com/articles.php?article_ id=2969. Accessed Sep 252010.

141. Wickramasinghe N, Gupta JND, Sharma SK. Creating KnowledgeBased Healthcare Organizations. London (UK): Idea Group; 2005.

142. Wickramasinghe N, Schaffer JL. Creating knowledge-driven healthcare processes with the intelligence continuum. Int J Electron Healthc. 2006;2(2):164-174.

143. Lavis JN. Research, public policymaking, and knowledge-translation processes: Canadian efforts to build bridges. J Contin Educ Health Prof. 2006;26(1):37-45.

144. Lavis JN, Robertson D, Woodside JM, McLeod CB, Abelson J; Knowledge Transfer Study Group. How can research organizations more effectively transfer research knowledge to decision makers? Milbank Q. 2003;81(2):221-248.

145. Yalnizyan A. Getting Better Health Care: Lessons from (and for) Canada. Ottawa (ON): Canadian Centre for Policy Alternatives; 2006:78.

146. Ballay JF. Tous managers du savoir. Paris: Éditions d'Organisation; 2002.

147. Foray D. L'économie de la connaissance. Paris: La Découverte; 2000.

148. Cookson R. Evidence-based policy making in health care: what it is and what it isn't. J Health Serv Res Policy. 2005;10(2): $118-121$.

149. Dobrow MJ, Goel V, Upshur RE. Evidence-based health policy: context and utilisation. Soc Sci Med. 2004;58(1):207-217.

150. Gagnon F, Turgeon J, Dallaire C. Healthy public policy: a conceptual cognitive framework. Health Policy. 2007;81(1):42-55

151. Mitton C, Adair CE, McKenzie E, Patten SB, Waye Perry B. Knowledge transfer and exchange: review and synthesis of the literature. Milbank Q. 2007;85(4):729-768.

152. Herie M, Martin GW. Knowledge diffusion in social work: a new approach to bridging the gap. Soc Work. 2002;47(1):85-95.

153. Ginsburg LR, Lewis S, Zackheim L, Casebeer A. Revisiting interaction in knowledge translation. Implement Sci. 2007;2(1):34.

154. Wright MO, Knobloch MJ, Pecher CA, Mejicano GC, Hall MC. Clinical decision support systems use in Wisconsin. WMJ. 2007; 106(3):126-129.

155. Macintyre S, Chalmers I, Horton R, Smith R. Using evidence to inform health policy: case study. BMJ. 2001;322(7280):222-225.

156. Signal L, Martin J, Reid P, et al. Tackling health inequalities: moving theory to action. Int J Equity Health. 2007;6(1):12.
157. Siegrist J, Marmot M. Social Inequalities in Health. New Evidence and Policy Implications. London (UK): Oxford University Press; 2006.

158. Wallace BC, editor. Toward Equity in Health. A New Global Approach to Health Disparities. New York: Springer; 2009.

159. Lapaige V. 'Integrated knowledge translation' for globally oriented public health practitioners and scientists: framing together a sustainable transfrontier knowledge translation vision. J Multidiscip Healthc. 2010;3:33-47.

160. Bohman J. Social critics, collective actors and public deliberation: innovation and change in deliberative democracy. In: Bohman J, editor. Public Deliberation: Pluralism, Complexity and Democracy. Cambridge (MA): MIT Press; 1996:197-236.

161. Bulmer M. The Use of Social Research: Social Investigation in Public Policy-Making. London: Allen and Unwin; 1982.

162. Huberman M. Predicting conceptual effects in research utilization: looking with both eyes. Knowl Soc. 1989;2(3):6-24.

163. Pelz DC. Some expanded perspectives on use of social science in public policy. In: Yinger JM, Cutler SJ, editors. Major Social Issues: A Multidisciplinary View. New York: Free Press; 1978: 346-357.

164. Weiss CH. The many meanings of research utilization. Public Adm Rev. 1979;39:426-431.

165. Denis JL, Lehoux P, Champagne F. A knowledge utilization perspective on fine-tuning dissemination and contextualizing knowledge. In: Lemieux-Charles L, Champagne F, editors. Using Knowledge and Evidence in Health Care: Multidisciplinary Perspectives. Toronto, Buffalo, London: University of Toroto Press; 2004:18-40.

166. Gibbons M, Limoges C, Nowotny H, Schwartzman S, Scott P, Trow M. Introduction. In: Gibbons M, Limoges C, Nowotny H, Schwartzman S, Scott P, Trow M, editors. The New Production of Knowledge: The Dynamics of Science and Research in Contemporary Societies. London: Sage; 1994:1-16.

167. Nutley S, Walters I, Davies HTO. Using Evidence. How Research Can Inform Public Services. Bristol (UK): Policy Press; 2007.

168. Grimshaw J. KT research. CIHR IHSPR-IPPH 7th Annual Summer, 'Innovation in Knowledge Translation Research and Knowledge Translation', NAV Canada Training and Conference Centre; Jun 22-25 2008; Cornwall, Ontario.

169. Salsberg J. Integrating knowledge translation through participatory research. CIHR IHSPR-IPPH 7th Annual Summer, 'Innovation in Knowledge Translation Research and Knowledge Translation', NAV Canada Training and Conference Centre; Jun 22-25 2008; Cornwall, Ontario.

170. Cohen SG. Complex collaborations in the new global economy. Organ Dyn. 2002;31(2):117-133.

171. Haythornthwaite C. Learning and knowledge networks in interdisciplinary collaborations. J Am Soc Inf Sci Technol. 2006;57(7): 1079-1092.

172. Communiqué de presse. L'Institut de recherche de l'Hôpital d'Ottawa reçoit $12 \mathrm{M} \$$ pour diriger un réseau national chargé de mettre à profit des résultats des recherches cliniques pour améliorer la santé. Ottawa (ON): Communications et Relations publiques, Institut de recherche de l'Hôpital d'Ottawa (IRHO); Apr 302009.

173. Bezama A, Szarka N, Navia R, Konrad O, Lorber KE. Lessons learned for a more efficient knowledge and technology transfer to South American countries in the fields of solid waste and contaminated sites management. Waste Manage Resour. 2007;25(2):148-161.

174. Booth W. NIH scientists agonize over technology transfer. Science. 1989;243(4887):20-21.

175. Fontes M. The process of transformation of scientific and technological knowledge into economic value conducted by biotechnology spin-offs. Technovation. 2005;25(4):339-347.

176. Grossi E. Technology transfer from the science of medicine to the real world: the potential role played by artificial adaptive systems. Subst Use Misuse. 2007;42(2-3):267-304.

177. Kaiser J. Technology transfer: U.S. scientists faulted on biotech consulting. Science. 2004;304(5675):1222. 
178. Kim Y. Technology transfer. Conf Proc IEEE Eng Med Biol Soc. 2004;7:5139.

179. August GJ, Lee SS, Bloomquist ML, Realmuto GM, Hektner JM. Dissemination of an evidence-based prevention innovation for aggressive children living in culturally diverse, urban neighborhoods: the Early Risers effectiveness study. Prev Sci. 2003;4(4): 271-286.

180. Denis JL, Hebert Y, Langley A, Lozeau D, Trottier LH. Explaining diffusion patterns for complex health care innovations. Health Care Manage Rev. 2002;27(3):60-73.

181. Graham ID, Logan J. Innovations in knowledge transfer and continuity of care. Can J Nurs Rev. 2004;36(2):89-103.

182. Battista RN. Innovation and diffusion of health-related technologies. A conceptual framework. Int J Technol Asses Health Care. 1989; 5(2):227-248.

183. Landry R, Becheikh N, Amara N, et al. Innovation dans les services publics et parapublics à vocation sociale. Rapport de la revue systématique des écrits. Québec (QC): Chaire FCRSS/IRSC sur le transfert des connaissances et l'innovation, Département de management, Université Laval; 2007.

184. Wensing M, van der Weijden T, Grol R. Implementing guidelines and innovations in general practice: which interventions are effective? $\mathrm{Br} J$ Gen Pract. 1998;48(427):991-997.

185. Estabrooks CA, Derksen L, Winther C, et al. The intellectual structure and substance of the knowledge utilization field: a longitudinal author co-citation analysis, 1945 to 2004. Implement Sci. 2008;3: 49-61.

186. Brown CP, Propst SM, Woolley M. Report: helping researchers make the case for science. Sci Commun. 2004;25(3):294-303.

187. Howard K, Peters J. Managing management research: presenting the findings. Manage Decis. 1990;28(5):43-56.

188. Huberman M, Gather Thuler M. De la recherche à la pratique: éléments de base. Berne (Suisse): Peter Lang; 1991.

189. Jacobson N, Butterill D, Goering P. Organizational factors that influence university-based researchers' engagement in knowledge transfer activities. Sci Commun. 2004;25(3):246-259.

190. Kramer DM, Cole DC, Leithwood K. Doing knowledge transfer: engaging management and labor with research on employee health and safety. Bull Sci Technol Soc. 2004;24(4):316-330.

191. Newton MS, Estabrooks CA, Norton P, Birdsell JM, Adewale AJ, Thornley R. Health researchers in Alberta: an exploratory comparison of defining characteristics and knowledge translation activities. Implement Sci. 2007;2:1.

192. Thompson GN, Estabrooks CA, Degner LF. Clarifying the concepts in knowledge transfer: a literature review. $J$ Adv Nurs. 2006;53(6): 691-701.

193. van der Sanden MCA, Meijman FJ. Evidence-based science communication: an essay. Sci Commun. 2004;25(3):272-287.

194. Stetler CB. Stetler model. In: Rycroft-Malone J, Bucknall T, editors. Models and Frameworks for Implementing Evidence-Based Practice. Linking Evidence to Action. Chichester (UK): Wiley-Blackwell and Sigma Theta Tau International; 2010:51-82.

195. Logan J, Graham ID. The Ottawa model of research use. In: Rycroft-Malone J, Bucknall T, editors. Models and Frameworks for Implementing Evidence-Based Practice. Linking Evidence to Action. Chichester (UK): Wiley-Blackwell and Sigma Theta Tau International; 2010:83-108.

196. Rycroft-Malone J. Promoting action on research implementation in health services. In: Rycroft-Malone J, Bucknall T, editors. Models and Frameworks for Implementing Evidence-Based Practice. Linking Evidence to Action. Chichester (UK): Wiley-Blackwell and Sigma Theta Tau International; 2010:109-136.

197. Titler M. Iowa model of evidence-based practice. In: RycroftMalone J, Bucknall T, editors. Models and Frameworks for Implementing Evidence-Based Practice. Linking Evidence to Action. Chichester (UK): Wiley-Blackwell and Sigma Theta Tau International; 2010: 137-146.
198. Dobbins M. Dissemination and use of research evidence for policy and practice: a framework for developing, implementing, and evaluating strategies. In: Rycroft-Malone J, Bucknall T, editors. Models and Frameworks for Implementing Evidence-Based Practice. Linking Evidence to Action. Chichester (UK): Wiley-Blackwell and Sigma Theta Tau International; 2010:147-168.

199. Mazurek Melnyk B, Fineout-Overholt E. ARCC (Advancing Research and Clinical practice through Collaboration): a model for system-wide implementation and sustainability of evidence-based practice. In: RycroftMalone J, Bucknall T, editors. Models and Frameworks for Implementing Evidence-Based Practice. Linking Evidence to Action. Chichester (UK): Wiley-Blackwell and Sigma Theta Tau International; 2010: 169-184.

200. Pearson A. The Joanna Briggs Institute model of evidence-based health care as a framework for implementing evidence. In:RycroftMalone J, Bucknall T, editors. Models and Frameworks for Implementing Evidence-based Practice. Linking Evidence to Action. Chichester (UK): Wiley-Blackwell and Sigma Theta Tau International; 2010: 185-206.

201. Graham ID, Tetroe JM. The knowledge to action framework. In: Rycroft-Malone J, Bucknall T, editors. Models and Frameworks for Implementing Evidence-based Practice. Linking Evidence to Action. Chichester (UK): Wiley-Blackwell and Sigma Theta Tau International; 2010:207-219.

202. Belkhodja O, Amara N, Landry R, Ouimet M. The extent and organizational determinants of research utilization in Canadian health services organizations. Sci Commun. 2007;28(3):377-417.

203. Livingood WC, Coughlin S, Bowman W, Bryant T 3rd, Goldhagen J. Application of economic impact analysis to a local public health agency and its 'Academic Health Department'. Public Health Rep. 2007;122(1);27-36.

204. Frank J, di Ruggiero E, Mowat D, Medlar B. Developing knowledge translation capacity in public health: the role of the National Collaborating Centres. Can J Public Health. 2007;98(4): $11-12$.

205. Agrawal A. University-to-industry knowledge transfer: literature review and unanswered questions. Int $J$ Manage Rev. 2001;3(4): 285-302.

206. Coates PM. Evidence-based reviews in support of health policy decisions. J Natl Cancer Inst. 2007;99(14):1059.

207. Dobbins M, Rosenbaum P, Plews N, Law M, Fysh A. Information transfer: what do decision makers want and need from researchers? Implement Sci. 2007;2:20.

208. Shamian J, El-Jardali F. Healthy workplaces for health workers in Canada: knowledge transfer and uptake in policy and practice. Healthc Pap. 2007;7:6-25.

209. Wharam JF, Daniels N. Toward evidence-based policy making and standardized assessment of health policy reform. JAMA. 2007;298(6): 676-679.

210. Aita M, Richer MC, Héon M. Illuminating the processes of knowledge transfer in nursing. Worldviews Evid Based Nurs. 2007;4(3): 146-155.

211. Abrahamian H, Schueller A, Mauler H, Prager R, Irsigler K. Transfer of knowledge from the specialist to the generalist by videoconferencing: effect on diabetes care. J Telemed Telecare. 2002;8(6):350-355.

212. Blunt RE, Walsh KA, Ashton DK, Viant MR, Chipman JK. Knowledge transfer initiative between molecular biologists and environmental researchers and regulators. Environ Sci Pollut Res Int. 2007;14(5): 293-296.

213. Hilliard N, Jenkins R, Pashayan N, Powles J. Informal knowledge transfer in the period before formal health education programmes: case studies of mass media coverage of HIV and SIDs in England and Wales. BMC Public Health. 2007;7(1):293.

214. Lapaige V. Santé mentale, communautés et environnement ; l'utlilté d'une d'intégration pour les formateurs et officers-citoyens due transfert de connaisances. Quebec, QC: Laval University; 2010; Dec 9. 
215. Intergovernmental Panel on Climate Change. Summary for policymakers. In: Parry ML, Canziani OF, Palutikof JP, van der Linden PJ, Hanson CE. Climate Change 2007: Climate Change Impacts, Adaptation and Vulnerability. Working Group II Contribution to the Intergovernmental Panel on Climate Change Fourth Assessment Report. Cambridge (UK): Cambridge University Press; 2007:7-22.

216. Confalonieri U, Menne B, Akhtar R, et al. Human health. In: Parry ML, Canziani OF, Palutikof JP, van der Linden PJ, Hanson CE. Climate Change 2007: Climate Change Impacts, Adaptation and Vulnerability. Working Group II Contribution to the Intergovernmental Panel on Climate Change Fourth Assessment Report. Cambridge (UK): Cambridge University Press; 2007:391-431.

217. Smith K. Symposium introduction. Mitigating, adapting, and suffering: how much of each? Annu Rev Public Health. 2008;29:23-25.

218. McMichael AJ. Population, environment, disease, and survival: past patterns, uncertain futures. Lancet. 2002;359(9312):1145-1148.

219. McMichael AJ, Woodruff RE, Hales S. Climate change and human health: present and future risks. Lancet. 2006;367(9513):859-869.

220. Patz JA, Campbell-Lendrum D, Holloway T, Foley JA. Impact of regional climate change on human health. Nature. 2005;438(7066):285.

221. Leary N, Adejuwon J, Bailey W, et al. For whom the bell tolls: vulnerabilities in a changing climate. A synthesis from the AIACC Project. AIACC Working Paper No. 21, January 2006

222. McLeman R. Impacts of population change on vulnerability and the capacity to climate change and variability: a typology based on lessons from 'hard country'. Popul Environ. 2010;31(5):286-316.

223. Galea S. Macrosocial Determinants of Population Health. New York: Springer; 2007

224. Santé Canada. Climate Change and Health: A Policy Primer. Ottawa (ON): Travaux publics et Services gouvernementaux Canada; 2003.

225. Direction de la santé publique. Les souris sylvestres dans les chalets. un risque sérieux pour la santé. Agence de développement de réseaux locaux de services de santé et de services sociaux de la Mauricie et du Centre-du-Québec. Available from: http://www.agencesss04.qc.ca/ communiques/2005/com1905051.pdf. Accessed Oct 22008.

226. Friel S, Marmot M, McMichael AJ, Kjellstrom T, Vagero D. Global health equity and climate stabilization: a common agenda. Lancet. 2008;372(9650):1677-1683

227. Beaudoin CE. News, social capital and health in the context of Katrina. $J$ Health Care Poor Underserved. 2007;18(2):418-430.

228. Organization for Economic Co-operation and Development. Valuation of Environment-Related Health Impacts with a Particular Focus on Children. Available from: http://www.oecd.org/document/60/0,3343, en_21571361 _36146795_36146876_1_1_1_1,00.html. Accessed Sep 102009.

229. Bunyavanich S, Landrigan CP, McMichael AJ, Epstein PR. The impact of climate change on child health. Ambul Pediatr. 2003;3(1):44-52.

230. Bélanger D, Gosselin P, Valois P, Abdous B. Vagues de chaleur au Québec méridional: Adaptations actuelles et suggestions d'adaptations futures. Québec (QC): Institut national de santé publique du Québec. Available from: http://www.inspq.qc.ca/publications/ default.asp?E=p\&Theme=8. Accessed Sep 202009 .

231. Séguin J, Clarke KL. Introduction. In: Santé Canada [Séguin J, editor]. Santé et changements climatiques: Évaluation des vulnérabilités et de la capacité d'adaptation au Canada. Ottawa (ON): Santé Canada; 2008:1-26.

232. Adger WN. Vulnerability. Glob Environ Change. 2006;16(3): 268-281.

233. Warren FJ, Egginton PA. Information de base: concepts, aperçus, approches. In: Lemmen DS, Warren FJ, Lacroix J, Bush E, editors. Vivre avec les changements climatiques au Canada: édition 2007. Ottawa (ON): Gouvernement du Canada; 2008:27-56.

234. Smit B, Burton I, Klein RJT, Street R. The science of adaptation: a framework for assessment. Mitigation Adapt Strateg Glob Change. 1999;4:199-213.

235. Yohe GW, Tol RSJ. Indicators for social and economic coping capacity - moving toward a working definition of adaptive capacity. Glob Environ Change. 2002;12(1):25-40.
236. Kelly PM, Adger WN. Theory and practice in assessing vulnerability to climate change and facilitating adaptation. Clim Change. 2000; 47(4):325-352.

237. DesJarlais C, Bourque A, Décoste R, et al. S'adapter aux changements climatiques. Montréal (QC): Consortium Ouranos; 2004.

238. Smi B, Pilifosova O. From adaptation to adaptive capacity and vulnerability reduction. In: Smith JB, Klein RJT, Huq S, editors. Climate Change, Adaptive Capacity and Development. London (UK): Imperial College Press; 2003:9-28.

239. Brooks N, Adger WN, Kelly PM. The determinants of vulnerability and adaptive capacity at the national level and the implications for adaptation. Glob Environ Change. 2006;15(2):151-163.

240. Füssel HM, Klein RJT. Conceptual Frameworks of Adaptation to Climate Change and Their Applicability to Human Health. Potsdam (Germany): Potsdam Institute for Climate Impact Research; 2004.

241. Kovats S, Ebi KL, Menne B. Methods of Assessing Human Health Vulnerability and Public Health Adaptation to Climate Change. Organisation mondiale de la santé, Santé Canada, Organisation météorologique mondiale, Programme des Nations Unies pour l'environnement. Available from: http://www.euro.who.int/InformationSources/Publications/ Catalogue/20041118_9. Accessed Sep 232009.

242. Füssel HM, Klein RJT. Climate change vulnerability assessments: an evolution of conceptual thinking. Clim Change. 2006;75(3): 301-329.

243. Stern N. The Economics of Climate Change: The Stern Review. New York: Cambridge University Press; 2006.

244. Ackerman F, Stanton EA, Hope C, Alberth S, Fisher J, Biewald B. The Cost of Climate Change: What We Will Pay If Global Warming Continues Unchecked. New York: Natural Resources Defence Council; 2008. Available from: http://www.nrdc.org/globalwarming/cost.pdf. Accessed July 22009.

245. Adger WN. Social aspects of adaptive capacity. In: Smith JB, Klein RJT, Huq S. Climate Change, Adaptive Capacity and Development. London: Imperial College Press; 2003:29-49.

246. Klinenberg E. A Social Autopsy of Disaster in Chicago. Chicago (IL): University Press; 2003.

247. Prüss-Üstün A, Corvalan C. Prévenir la maladie grâce à un environnement sain - Une estimation de la charge de morbidité imputable à l'environnement (Résumé). Genève (Suisse): Organisation mondiale de la Santé. Available from: http://www.whqlibdoc.who.int/ publications/2006/924259201_fre.pdf. Accessed Sep 32009.

248. Organisation de coopération et de développement économiques. Aspects économiques de l'adaptation au changement climatique - Coûts, bénéfices et instruments économiques. Éditions OCDE; 2008.

249. Organisation mondiale de la Santé. Rapport sur la santé dans le monde 2002: réduire les risques et promouvoir la vie saine. Genève (Suisse): Auteur; 2002.

250. Prüss-Üstün A, Zeeb H, Mathers C, Repacoli M, editors. Solar ultraviolet radiation: Global burden of disease from ultraviolet radiation. Environmental Burden of Disease Series. Vol. 13. Geneva (Switzerland): World Health Organization; 2006:285.

251. Kovats S, Ebi K. Heatwaves and public health in Europe. Eur J Public Health. 2006;16(6):592-599.

252. Kosatsky T. The 2003 european heat waves. Eurosurveillance. 2006;10(7):552. Available from: http://www.eurosurveillance.org/ ViewArticle. aspx? Articled=552. Accessed Aug 292009.

253. Kovats RS, Hajat S. Heat stress and public health: a critical review. Annu Rev Public Health. 2008;29:41-55.

254. Manuel J. In Katrina's wake. Environ Health Perspect. 2006;114: A32-A39.

255. Klein RJT, Nicholls RJ, Mimura N. Coastal adaptation to climate change: can the IPCC technical guidelines be applied? Mitigation Adapt Strateg Glob Change. 1999;4(3-4):239-252.

256. Ministère du Développement durable de l'Environnement et des Parcs du Québec. Loi sur le développement durable L.R.Q. chapitre D-8.1.1, Éditeur officiel du Québec. Québec (QC): Auteur. Available from: http://www.mddep.gouv.qc.ca/developpement/loi.htm. Accessed Sep 242009. 
257. Ouranos. Programmation scientifique. Montréal (QC): Auteur. Available from: http://www.ouranos.ca/programmation/prog_f.html. Accessed Aug 22008.

258. Institut national de santé publique du Québec. Mesures individuelles et collectives pour prévenir la transmission du virus du Nil occidental - Éléments pour un plan global d'intervention. Québec (QC): Auteur; 2005.

259. Institut national de santé publique du Québec. Épidémiologie et effets de l'infection par le virus du Nil occidental sur la santé humaine-Mise à jour 2004. Québec (QC): Auteur; 2005.

260. Ministère de la Sécurité publique du Québec. Au service de votre sécurité. Québec (QC): Auteur. Available from: http://www.msp.gouv. qc.ca/secivile/soutcito/asvs_fr_mrci.pdf. Accessed Sep 172009.

261. Ministère de la Sécurité publique du Québec. Programmes actuels d'assistance d'aide financière aux sinistrés. Québec (QC): Auteur; 2003. Available from: http://www.msp.gouv.qc.ca/secivile/secivile. asp?txtSection=afs\&txtCategorie=progactuel. Accessed Oct 22008.

262. Bouden M, Moulin B, Gosselin P, et al. La géo-stimulation de l'infection du virus du Nil occidental en fonction du climat: un outil de gestion du risqué en santé publique. Dans ' $S$ 'adapter aux changements climatiques au Canada en 2005: comprendre les risques et renforcer nos capacités', Conférence du Réseau canadien de recherche sur les impacts climatiques et l'adaptation (C-CIARN); 2005 May; Montréal, Québec.

263. Gosselin P, Lebel G, Rivest S, Douville-Fradet M. The integrated system for public health monitoring of West Nile Virus (ISPHMWNV): a real-time GIS for surveillance and decision-making. Int $J$ Health Geogr. 2005;4:21.

264. Bélanger D, Gosselin P, Valois P, Abdous B. Vagues de froid au Québec méridional: Adaptations actuelles et suggestions d'adaptations futures. Québec (QC): Institut national de santé publique du Québec. Available from: http://www.inspq.qc.ca/publications/default. asp?E=p\&Theme=8. Accessed Sep 202008.

265. Bélanger D, Gosselin P. Changements climatiques au Québec méridional: Perceptions de la population générale et suggestions d'adaptations futures. Québec (QC): Institut national de santé publique du Québec. Available from: http://www.inspq.qc.ca/publications/ default.asp?E=p\&Theme=8. Accessed Sep 202009.

266. Bélanger D, Gosselin P, Poitras P. Changements climatiques au Québec méridional: Perceptions des gestionnaires municipaux et de la santé publique. Québec (QC): Institut national de santé publique du Québec. Available from: http://www.inspq.qc.ca/publications/default. asp?E $=$ p\&Theme=8. Accessed Sep 202009.
267. Giguère M, Gosselin P. Eau et santé: Examen des initiatives actuelles d'adaptation aux changements climatiques au Québec. Québec (QC): Institut national de santé publique. Available from: http://www.inspq.qc.ca/publications/default.asp?E=p\&Theme=8. Accessed Sep 202009.

268. Giguère M, Gosselin P. Événements climatiques extrêmes et santé: Examen des initiatives actuelles d'adaptation aux changements climatiques au Québec. Québec (QC): Institut national de santé publique. Available from: http://www.inspq.qc.ca/publications/ default.asp?E=p\&Theme=8. Accessed Sep 202009.

269. Giguère M, Gosselin P. Maladies zoonotiques et à transmission vectorielle: Examen des initiatives actuelles d'adaptation aux changements climatiques au Québec. Québec (QC): Institut national de santé publique. Available from: http://www.inspq.qc.ca/publications/default. asp?E $=\mathrm{p} \&$ Theme=8. Accessed Sep 202009.

270. Giguère M, Gosselin P. Vagues de chaleur, effet d'îlot thermique urbain et santé: Examen des initiatives actuelles d'adaptation aux changements climatiques au Québec. Québec (QC): Institut national de santé publique. Available from: http://www.inspq.qc.ca/publications/ default.asp?E=p\&Theme=8. Accessed Sep 202009.

271. Ebi KL, Smith JB, Burton I. Integration of Public Health with Adaptation to Climate Change: Lessons Learned and New Directions. London (UK): Taylor and Francis; 2005.

272. Menne B, Bertollini R. Health and climate change: a call for action. BMJ. 2005;331(7528):1283-1284.

273. Justesen S. Innoversity in communities of practice. In: Hildreth $\mathrm{P}$, Kimble C. Knowledge Networks. Innovation Through Communities of Practice. London (UK): Idea Group Publishing; 2004:79-79.

274. Hirsh Hadorn G, Biber-Klemm S, Grossenbacher-Mansuy W, et al. The emergence of transdisciplinarity as a form of research. In: Hirsh Hadorn G, Hoffmann-Riem H, Biber-Klemm S, et al. Handbook of Transdisciplinary Research. Bern (Switzerland): Springer Sciences and Business Media BV; 2008:19-39.

275. Barry MM, Allegrante JP, Lamarre MC, Ault M, Taub A. The Galway Consensus Conference: international collaboration on the development of core competences for health promotion and health education. Global Health Promot. 2009;16(2):5-11.
Advances in Medical Education and Practice

\section{Publish your work in this journal}

Advances in Medical Education and Practice is an international, peerreviewed, open access journal that aims to present and publish research on Medical Education covering medical, dental, nursing and allied healthcare professional education. The journal covers undergraduate education, postgraduate training and continuing medical education

\section{Dovepress}

including emerging trends and innovative models linking education, research, and healthcare services. The manuscript management system is completely online and includes a very quick and fair peer-review system. Visit http://www.dovepress.com/testimonials.php to read real quotes from published authors. 